\title{
Vulvar Cancer Pathologic TNM Finding v7
}

National Cancer Institute

\section{Source}

National Cancer Institute. Vulvar Cancer Pathologic TNM Finding v7. NCI Thesaurus. Code C89438.

A pathologic finding about one or more characteristics of vulvar cancer, following the rules of the TNM AJCC V7 classification system. 